\title{
The Obligation on an Intervening State to Respect the Host State's IHL and IHRL Obligations in an Intervention by Invitation: An Analysis of the Saudi Intervention in Yemen
}

\author{
Louis Koen $^{* *}$ \\ Brooke Hanson $^{* * *}$
}

DOI: $10.21827 / 5 b 51 \mathrm{~d} 5 \mathrm{a} 593268$

\section{Keywords \\ CONSENT, VARIATION OF INTERNATIONAL OBLIGATIONS, INTERNATIONAL HUMANITARIAN LAW, INTERVENTION BY INVITATION}

\begin{abstract}
Interventions by invitation of the government have been attracting increasing interest from legal scholars in recent years. This increased interest can be attributed to the increasing frequency at which States, including Saudi Arabia in Yemen, use such invitations as a justification for the use of force in the territory of the host State. This paper considers these scholarly contributions and goes on to assess the limits of consent on which comparatively less scholars have focused. The paper concludes by arguing that the intervening State is constrained in its actions, within the host state, by the IHL and IHRL obligations binding on the host state.
\end{abstract}

\section{Introduction}

Consent, within the sphere of international law, has been argued to play three specific roles: 'to create, amend and excuse other States' wrongdoings. ${ }^{1}$ Explained in these terms, consent can be said to be both the pathway in which to create international law obligations, as well as the tool which releases States from certain obligations. As the complexity of armed conflicts in the world has changed drastically in the past several decades, so has the issue of consent and increasingly what constitutes valid consent and how far consent goes in excusing wrongdoing. A main point of contention arises surrounding the application of International Humanitarian Law (IHL) and International Human Rights Law (IHRL) either separately, or concurrently, and how this affects the enforceability of certain international law agreements by both consenting and intervening States.

This paper will briefly explore some of these issues with reference to the specific example of Saudi Arabia's intervention by invitation taking place in Yemen. Firstly, the relationship between consent and the use of force, in rendering the use of force lawful in as far as it removes the use of force from the jus ad bellum framework. Secondly, it must

\footnotetext{
This article is the wining submission of the 2018 student writing competition of the Groningen Journal of International Law. The authors are grateful to the University of Johannesburg for access to its databases without which this research would not have been possible. The authors are also particularly grateful to Harry Jijita, Alysha Wolfaardt, Candice Bonner and Lee Menachemi for their support and comments on an earlier draft of this article. All mistakes and views remain those of the authors.

${ }^{* *} 4^{\text {th }}$ Year LLB Candidate at the University of Johannesburg.

${ }^{* * *} 4^{\text {th }}$ Year LLB Candidate at the University of Johannesburg.

1 Deeks, A., "Consent to Use of Force and International Law Supremacy", 54 Harvard International Law Journal, (2013), 1-60, 7.
} 
be examined whether a use of force that has been removed from the framework of $j u s$ ad bellum would per se be lawful under jus in bello. Thirdly, this paper will argue that although it appears to be possible for States to alter their international obligations, as between itself and a third state, through an agreement such alterations are not possible in the case of an obligation erga omnes or where the obligation in question can not truly be seen as one regulating the strictly bilateral obligations between States. Lastly, the suggestion that a distinction between positive and negative international obligations should be made, and at very least, both parties in the example should be bound to the negative obligations, to prohibit consent from being used as an avenue for unlawful use of force and contravention of international law.

\section{Intervention by Invitation and Jus Ad Bellum}

International Law generally prohibits the use of force against the territorial integrity or political independence of any State. ${ }^{2}$ There are, however, exceptions provided in jus ad bellum such as self defence and Security Council approval. ${ }^{3}$ The granting of consent by one State to another is also regarded as a lawful use of force. ${ }^{4}$ This use of force is not, however, rendered lawful by the operation of jus ad bellum but rather removes the use of force from its framework. ${ }^{5}$ This is as jus ad bellum largely provides an excused violation of sovereignty whereas the use of force pursuant to valid consent does not violate sovereignty as it is 'a manifestation of that state's agency and political independence', 6 to the extent that the actions remain within the limits of that consent. ${ }^{7}$

\section{A. Article 20 DASR}

Article 20 of the International Law Commission's Draft Articles on State Responsibility (DASR) specifically sets out that consent by a state is assumed to carry the capacity necessary to preclude wrongfulness of acts that would have otherwise been wrongful in international law. ${ }^{8}$ This is not intended to suggest that consent by one state gives license to another state to do as it pleases, even when there was an invitation to intervene. An example of this can be found in the Nicaragua case, where the ICJ mentioned that intervention even by invitation is wrongful where coercion is used and, due to a States' weak bargaining position, that State finds itself unable to make choices freely. ${ }^{9}$ This reiterates the basis for consent in Article 20 of the DASR which states that for consent to

Article 2(4), United Nations, Charter of the United Nations (1945) 1 UNTS XVI (UN Charter).

Choquette, R., "A Rebuttable Presumption against Consensual Nondemocratic Intervention", 55 Columbia Journal of Transnational Law, (2016) 138-177, 144.

4 See International Court of Justice (ICJ), Military and Paramilitary Activities in and Against Nicaragua (Nicaragua v. U.S.), ICJ Reports 1986, June 27 1986; and ICJ, Armed Activities on the Territory of the Congo (Dem. Rep. Congo v. Uganda), ICJ Reports 2005, 19 December 2005, paras 42-54.

5 Byrne, M., "Consent and the use of force: an examination of 'intervention by invitation' as a basis for US drone strikes in Pakistan, Somalia and Yemen." 3(1) Journal on the Use of Force and International Law, (2016), 97-125.

6 Ibid.

7 International Law Commission, Draft Articles on Responsibility of States for Internationally Wrongful Acts, November 2001, Supplement No. 10 (A/56/10), Article 20.

8 Fox, G., "Intervention by Invitation" in Weller, M. ed., The Oxford Handbook on the Use of Force, (Oxford University Press 2015), 821.

$9 \quad$ Ibid. 
truly be valid, the consent itself must at least a true and voluntary representation of the States' will. ${ }^{10}$

\section{B. Consent during a civil war}

The legal literature on consent has increasingly been focused on the prerequisites for valid consent and the controversy surrounding the capability of a State to consent to an intervention in the midst of a civil war. ${ }^{11}$ There has been broad support amongst international legal scholars for the principle that consent cannot be granted in the midst of a civil war since the adoption of the Institute du Troit's 1975 resolution on 'The Principle of Non-Intervention in Civil Wars' and Louise Doswald-Beck's seminal paper on consent in 1986 where she opined that 'there is, at least, a very substantial doubt whether a State may validly assist another government to suppress a rebellion. ${ }^{12}$ The increasingly frequent occurrence of states requesting the assistance of other states during the subsistence of in internal armed conflicts, ${ }^{13}$ although the extent to which such conflicts can be classified as a 'civil war' remains unclear, warranting a brief discussion on State practice in this area in as far as it relates to the situation in Yemen.

Le Mon examined several interventions by invitation in his paper on this topic including, amongst others, Lebanon, Chad, Sri Lanka, and Tajikistan in which almost all of these interventions received 'near-unanimous support for the intervention's legality'. ${ }^{14}$ This support came despite many of these conflicts arguably being considered a civil war. Vermeer and Akande have also pointed to the intervention by France in Mali in recent years in support thereof that state practice seemingly does not confirm any general prohibition on a states ability to intervene on behalf of the legitimate government in the midst of a civil war. ${ }^{15}$ Other scholars in turn have, however, argued that the intervention in Mali was only against terrorist groups and not those groups that may legitimately be seen as liberation movements. ${ }^{16}$

State practice in this area thus seems somewhat inconsistent and the extent to which a state may intervene in a civil war remains unclear. The underlying rationale behind the alleged prohibition on accepting an invitation to intervene in the midst of a civil war as respecting people's right to self-determination is, however, clear. ${ }^{17}$ It is submitted that if such a prohibition exists it clearly exists only in instances where the rebel group represent a clear manifestation of the will of the people. It is further

10 Byrne, M., "Consent and the Use of Force: An Examination of 'Intervention by Invitation' A a Basis for Drone Strikes in Pakistan, Somalia and Yemen",3 Journal on the Use of Force in International Law, (2016), 97- 125, 105.

11 See, Byrne, Supra nt. 5, Visser; L., "Russia's Intervention in Syria" 2015 at <ejiltalk.org/russiasintervention-in-syria/> (accessed 25 May 2018); Akande, D. and Vermeer, Z., "The Airstrikes against Islamic State in Iraq and the Alleged Prohibition on Military Assistance to Governments in Civil Wars" 2 February 2015 at <ejiltalk.org/the-airstrikes-against-islamic-state-in-iraq-and-the-alleged-prohibitionon-military-assistance-to-governments-in-civil-wars/> (accessed 25 May 2018) and Nenadic, S., "Lawfulness of New Zealand's Military Deployment to Iraq: Intervention by Invitation Tested", 12(3) N.Z. Y.B. Int'1 L., (2014), 3-78.

12 Doswald-Beck, L., "The Legal Validity of Military Intervention by Invitation of the Government" 56 British Yearbook of International Law, (1986), 189-252.

13 See inter alia Byrne, Supra nt. 5, 115 and Le Mon, C., "Unilateral Intervention by Invitation in Civil Wars: The Effective Control Test Tested" 35 Journal of International Law and Politics, (2003), 741-792.

14 Le Mon, Supra nt. 13, 791.

15 Akande, D. and Vermeer, Z., Supra nt. 11.

16 See amongst others Ruys, T. and Ferro, L., "Legality and Legal Implications of the Saudi-led Military Intervention in Yemen" at <ssrn.com/abstract=2685567> ( accessed 15 April 2018).

17 Ruys, T. and Ferro, L, Supra nt. 16. 
submitted that the mere fact that an armed group is capable of taking up arms against the State would not in itself imply that the group represents the will of the people. ${ }^{18}$

\section{Consent and legitimacy}

It is trite that valid consent can only be given by the legitimate government of the state concerned. ${ }^{19}$ The most significant question in the determination of the legitimacy of the government rests upon its control over the state. ${ }^{20}$ Traditionally, the focus had largely been on de facto control over the territory of the state. ${ }^{21}$ The International Law Association (ILA) more recently opined that a government is capable of consenting if it is the de jure government by virtue of being the constitutional government and/or democratically elected power. ${ }^{22}$ The ILA nevertheless still seems to imply that territorial control is the point of departure but that in instances where the de jure government still enjoys broad international recognition it will be capable of consenting. ${ }^{23}$

In the case of Yemen there is little dispute that President Hadi's government was de jure recognised as the legitimate government of Yemen with President Hadi having assumed office trough elections as required by Article 106(a) of the Constitution of Yemen. ${ }^{24} \mathrm{He}$ had, however, ostensibly lost de facto control over the state when he fled to Saudi Arabia, after his resignation, when the Yemeni capital, Sanaa, and later his last refuge in Aden was captured by Houthi rebels. ${ }^{25}$ President Hadi later rescinded his resignation and invited Saudi Arabia and its Gulf Cooperation Council (GCC) partners to use military force against the rebel forces. ${ }^{26}$

The International Community as a whole, except for a few states such as Iran, ${ }^{27}$ did not question the legitimacy of the invitation by President Hadi and broadly continued to recognise his government as the legitimate government of Yemen. Furthermore, the United Nations Security Council (hereafter the Security Council) in the preambular paragraph of Resolution 2216 reaffirmed its support for the legitimacy of President Hadi and called on 'all parties and Member States to refrain from taking any actions that undermine.... the legitimacy of the President of Yemen. ${ }^{28}$ It can therefore be concluded that despite President Hadi having lost de facto control over the territory of Yemen he was

18 Byrne, Supra nt. 5, 115.

19 Byrne, Supra nt. 5 107; ILC Articles and Commentary, par 6.

20 Ibid.

21 Fox, Supra nt. 8, 831.

22 Byrne, Supra nt. 5, 107 see also International Law Association Committee on the Use of Force, Washington Conference 'Report on Aggression and the Use of Force' (2014), (ILA Report) <www.ilahq.org/download.cfm/docid/DA12E88E-5E44-4151-9540DC83D4A0EA78>

23 ILA Report, Supra nt. 22, states at footnote 88 that "As a matter of international law, effective control is arguably the determinative factor for governmental authority. As stated in the Tinoco case, it is independence and control' that entitles an entity to be classed as a national personality: see Aguilar-Amory and Royal Bank of Canada Claims (1923) 1 RIAA 369, 381 (William H Taft). James Crawford has also noted, in reference to this arbitral decision, that "i]n the case of governments, the "standard set by international law" is so far the standard of secure de facto control of all or most of the state territory': Crawford, Brownlie's Principles, at 152." Byrne, Supra nt. 5, 107, however, opines that the ILA does not seemingly prefer either de jure or de facto control over the other.

24 Byrne, Supra nt. 5, 116.

25 Reuters, Ghobari, M. and Mukhashaf, M., "Yemen's Hadi flees to Aden and says he is still president", 21 February 2015, at <reuters.com/article/us-yemen-security/yemens-hadi-flees-to-aden-and-says-heis-still-president-idUSKBN0LP08F20150221> (accessed 12 April 2018).

26 BBC News, "Yemen's President Hadi asks UN to back intervention", 25 March 2015, at $<$ bbc.com/news/world-middle-east-32045984> (accessed 13 April 2018).

27 Wall Street Journal, Eqbali, A. and Fitch, A., "Iran Condemns Saudi Arabia's Military Intervention in Yemen”, 26 March 2015, at <wsj.com/amp/articles/iran-condemns-saudi-arabias-militaryintervention-in-yemen-1427366776> (accessed 13 April 2018).

28 SC Resolution 2216, 14 April 2015. 
capable of consenting to the intervention in light of the widespread international recognition of his government as the de jure government of Yemen. ${ }^{29}$

\section{The Removal of The Use of Force from the Framework of Jus Ad Bellum Does Not Per Se Render It Lawful Under Jus in Bello}

It is an established principle of international law that jus ad bellum and jus in bello are theoretically distinct bodies of law and remain separate. ${ }^{30}$ The use of force that is lawful under jus ad bellum would not therefore automatically be lawful under jus in bello. ${ }^{31}$ Similarly, it is submitted that the mere fact that the use of force has been removed from the framework of jus ad bellum would not similarly remove it from the framework of jus in bello. The obligations arising from jus in bello are nevertheless ostensibly not excluded from the wording of Article 20 of the ILC Articles on State Responsibility.

\section{A. Consent will not exclude wrongfulness where consent to a violation is excluded lex specialis}

The ILC Articles on State Responsibility are widely considered to be the most authoritative statement on state responsibility and broadly forming part of customary international law. ${ }^{32}$ The principles that consent can exclude State responsibility were also regarded as forming part of customary international law well before the adoption of the ILC Articles, ${ }^{33}$ wherefore it is not in dispute that consent can in certain instances exclude wrongfulness. It is, however, also clear that the provisions of the ILC Articles on State Responsibility can be excluded lex specialis. ${ }^{34}$ Article 55 of the DASR also clearly provides that it does not 'apply where and to the extent that the conditions for the existence of an internationally wrongful act or the content or implementation of the international responsibility of a State are governed by special rules of international law.'

It is therefore trite that treaties containing special provisions on responsibility for internationally wrongful acts may exclude the application of the DASR. The responsibility arising from grave breaches of IHL is a prominent example where Article 20 of the DASR will be excluded lex specialis. It is common to the Four Geneva Conventions of August 1949 that no State may excuse itself or any other state of any liability incurred by itself or by another 'High Contracting Party' in respect of grave breaches. $^{35}$

29 The striking similarities between the consent given by President Hadi and President Yanukovych of Ukraine and the diametrically opposed reaction of the international community falls beyond the scope of this paper. Suffice it to say that international law seemingly recognises the ability of a de jure government to consent only up until the point where a single new government has been established. In the case of President Yanukovych an interim government had already been established at the point when he fled to Russia. See in this regard Byrne, Supra nt. 5, 117 and Vermeer, Z., "The Jus ad Bellum and the Airstrikes in Yemen: Double Standards for Decamping Presidents? EJIL Talk, 30 April 2015, at $<$ ejiltalk.org/the-jus-ad-bellum-and-the-airstrikes-in-yemen-double-standards-for-decampingpresidents/> (accessed 13 April 2018).

30 Moussa, J., "Can jus ad bellum override jus in bello? Reaffirming the separation of the two bodies of law" 90 International Review of the Red Cross, (2008), 963-990, 965.

31 Ibid.

32 See ICSID, Corn Products International Inc., $v$ The United Mexican States, Case No. ARB(AF)/04/01, decision on responsibility (2008) (hereafter "Corn Products International").

33 Nicaragua v. U.S., Supra nt. 4.

34 Corn Products International, Supra nt. 32.

35 See Article 52, International Committee of the Red Cross (ICRC), Geneva Convention (II) for the Amelioration of the Condition of Wounded, Sick and Shipwrecked Members of Armed Forces at Sea, 12 August 1949, 75 UNTS 85; Article 51, ICRC, Geneva Convention (I) for the Amelioration of the Condition of the 


\section{B. Consent will not exclude wrongfulness in respect of a jus cogens norm}

It is uncontroversial that any consent granted violating a jus cogens norm is void. ${ }^{36}$ The Court of First Instance of the European Community has also held that:

International law [...] permits the inference that there exists one limit to the principle that resolutions of the Security Council have binding effect: namely, that they must observe the fundamental peremptory provisions of jus cogens. If they fail to do so, however improbable that may be, they would bind neither the Member States of the United Nations nor, in consequence, the Community. ${ }^{37}$

Therefore, not even the Security Council may take actions that violate a jus cogens norm. Yemen is therefore, even more so, clearly not capable of granting Saudi Arabia and/or its GCC partners the right to violate jus cogens norms within its territory. It is not necessary for purposes of this paper to establish an exhaustive list of jus cogens norms. Article 3 Common to the Four Geneva Conventions of 1949, however, enjoys wide acceptance as a jus cogens norm, ${ }^{38}$ wherefore Yemen and its allies are at a minimum required to comply with the obligations arising therefrom.

\section{A Consenting State Can in General Not Consent to Acts That It Itself Cannot Perform}

In the foregoing discussion it had been established that at a minimum consent cannot be given to acts that would violate a jus cogens norm, nor can the wrongfulness of an act be excluded in instances where the obligation in question, as lex specialis, provides that a State cannot excuse any states non-compliance. International legal scholars also increasingly agree that a state cannot generally consent to actions which it itself could not lawfully undertake. ${ }^{39}$ The extent to which an intervening state's action is constrained by the host state's international obligations, however, in turn depends to some extent on whether or not a host state can alter its existing international obligations as between itself and the intervening State through a subsequent agreement.

\section{A. States ability to alter international obligations}

It is trite that States generally have the ability to alter their international obligations through the operation of consent ${ }^{40}$ which form the basis of international law. ${ }^{41}$ In the case of a bilateral treaty, the ability to alter treaty obligations is generally uncontroversial where the parties thereto agree. It is also 'well understood that, in practice, rules of [general] international law can, by agreement, be derogated from in particular cases or as between particular parties. ${ }^{42}$ It is thus possible for Yemen to alter some customary

Wounded and Sick in Armed Forces in the Field, 12 August 1949, 75 UNTS 31; Article 148, ICRC, Geneva Convention (IV) relative to the Protection of Civilian Persons in Time of War, 12 August 1949, 75 UNTS 287.

36 Deeks, Supra nt. 1.

37 Judgment of the Court of First Instance of 21 September 2005 in Case T-306/01, Ahmed Ali Yusuf and Al Barakaat International Foundation v. Council of the European Union and Commission of the European Communities and Case T-315/01, para 281.

38 Byrne, Supra nt. 5, 122 at footnote 182 and the authorities therein.

39 Deeks, Supra nt. 1 and Byrne, Supra nt. 5, 116.

40 Deeks, Supra nt. 1.

41 Ibid.

42 See ILC, "Report of the Study Group of the International Law Commission- Fragmentation of International Law: Difficulties Arising From the Diversification and Expansion of International Law" 2006 at <legal.un.org/ilc/texts/instruments/english/draft_articles/1_9_2006.pdf> (accessed 13 April 
international law obligations binding on it through the conclusion of an 'agreement' with Saudi Arabia granting it consent to intervene. ${ }^{43}$

The extent to which a State may alter its international obligations arising from a multilateral treaty through the conclusion of a subsequent agreement, however, gives rise to significantly greater controversy. ${ }^{44}$ The ICJ has held in this regard that it is:

a generally recognized principle that a multilateral convention is the result of an agreement freely concluded upon its clauses and that consequently none of the contracting parties is entitled to frustrate or impair, by means of unilateral decisions or particular agreements, the purpose and raison d'être of the convention. $^{45}$

This statement seemingly confirms what is, at least in our minds, a sound principle of international law that Yemen cannot simply alter the entirety of its multilateral obligations trough granting Saudi Arabia consent.

Article 30 of the VCLT, however, appears to favour the lex posterior derogat lege prior rule in its provisions that where a State concludes a successive treaty, relating to the same subject-matter, with a State that is only a party to the latter treaty the parties' mutual rights and obligations shall be governed by the latter treaty. ${ }^{46}$ These provisions are nevertheless without prejudice to any question of state responsibility that may arise as a result of the breach of an international obligation through the conclusion or application of such subsequent treaty. ${ }^{47}$ Yemen could therefore still incur international responsibility in instances where Article 30 applies $^{48}$ if the subsequent treaty violates its obligations visà-vis another state.

It is furthermore clear that the provisions in Article 30 only apply to the extent that the agreement relates to the same subject matter. The legal literature on what constitutes the 'same subject-matter' is increasingly supportive of a relatively broad interpretation that is not limited thereto that the subsequent treaty must deal with the same branch of law, for example jus in bello. The test on whether an agreement falls within the same subject matter thus turns on 'whether the fulfilment of the obligation

2018) (hereafter "ILC study on the Diversification and Expansion of International Law"); ICJ, North Sea Continental Shelf cases (Federal Republic of Germany/Denmark; Federal Republic of Germany/Netherlands), ICJ Reports 1969, 20 February 1969, para 72. and Case Concerning the Continental Shelf (Tunisia/Libyan Arab Jamahiriya) (Merits), ICJ Reports 1982, 24 February 1982, para 24.

43 This would for obvious reasons not apply to principles of customary international law having obtained the status of a jus cogens norm. In light of the ICJ's relatively broad interpretation of what constitutes an agreement there is also an increasing consensus amongst legal scholars that the granting of consent by one state to another would constitute an international agreement. See in this regard inter alia Deeks, Supra nt. 39.

44 ILC study on the Diversification and Expansion of International Law, Supra nt. 42, 121.

45 ICJ, Reservations to the Convention on the Prevention and Punishment of the Crime of Genocide case (hereafter "Reservations to the Genocide Convention"), Advisory Opinion, ICJ Reports 1951, 28 May 1951, see also ILC study on the Diversification and Expansion of International Law, Supra nt. 42, 123.

46 Article 30(4)(b), Vienna Convention on the Law of Treaties, 22 May 1969, 1155 UNTS 331.

47 Ibid, Article 30(5) these provisions, however, apply to the state breaching the obligation. In instances where the host state thus violates an obligation binding on it, it would not affect the intervening state.

48 Interventions by Invitation are rarely initiated trough the conclusion of a 'treaty' in the strict sense of the word as defined in the VCLT. Given the I.C.J's broad application of the VCLT to other sources as an interpretive guide, including Security Council Resolutions, it is possible that Article 30 may find application in relation to the letter exchanged by the President of Yemen and the Saudi government initiating the Saudi intervention by invitation. See inter alia Kosovo Advisory Opinion. 
under one treaty affects the fulfilment of the obligation of another' ${ }^{49}$ If a subsequent agreement thus prevents the fulfilment of the obligations arising from the previous agreement or undermines its raison d'etre the latter agreement will thus generally apply to the obligations arising between two states.

It would therefore seem that, to a certain extent, Saudi Arabia may rely on a later agreement concluded between itself and Yemen even where such agreement would conflict with other obligations binding on Yemen. This is, however, an oversimplified view and will ultimately be affected by the nature of the obligation intended to be altered and the limits on the underlying rationale behind the international community's support for the lex posterior principle.

\section{B. Alteration of integral obligations and obligations erga omnes}

Although there is generally no strict hierarchy of norms in international law, the ILC has opined that there has 'never been any doubt about the fact that some considerations in the international world are more important than others and must be legally recognized as such. ${ }^{50}$ It is submitted that obligations erga omnes are such norms considered more important than other strictly bilateral norms and a strict presumption against it being derogated from by lex posterior or modification should exist. ${ }^{51}$

In the course of the ILC debates on the VCLT it was already emphasised that there are certain obligations that are of a more integral or interdependent character. ${ }^{52}$ These obligations were considered to be incapable of being reduced in any significant way to a reciprocal bilateral relationship between states. ${ }^{53}$ The more integral obligation, it was further explained, would then be less easily derogated from through a subsequent alteration or lex posterior. ${ }^{54}$

It is to these obligations of a more integral nature that the ICJ was also seemingly referring to in its Reservations to the Genocide Convention Advisory Opinion, in which it held that a party to such multilateral convention may not reach particular agreements that frustrate the purpose and raison d'être of the convention. ${ }^{55}$ It is therefore submitted that Yemen cannot alter its obligations under international law, having the status of an obligation erga omnes or if such obligations are incapable by their very nature of being reduced to operate in the bilateralist sense, through the conclusion of a subsequent agreement with Saudi Arabia.

The ICJ in the Palestinian Wall Case has also held that considering the importance of the rights concerned there is an obligation on all States not to recognise any conduct inconsistent with an obligation erga omnes. ${ }^{56}$ This obligation would therefore also apply to Saudi Arabia and, in turn, require it not to conclude an agreement with Yemen that would lead to Yemen violating its erga omnes obligations. It is submitted that Saudi Arabia would thus also have to interpret the limits of the consent granted by President

ILC study on the Diversification and Expansion of International Law, Supra nt. 42, 130.

Idem, p 167.

51 This is not, however, to suggest that obligations erga omnes create the same 'hierarchical' relationship between norms such as a jus cogens norm, which would clearly take preference over other norms.

52 Fitzmaurice, Third Report, Yearbook ... 1958 vol. II, p. 44, para. 91 see also Idem, 195.

53 ILC study on the Diversification and Expansion of International Law, Supra nt. 42, 195.

54 Ibid.

55 Reservations to the Genocide Convention, Supra nt. 45, 21.

56 Legal Consequences of the Construction of a Wall in the Occupied Palestinian Territory, Advisory Opinion, reproduced in document A/ES-10/273 and Corr.1. See also ILM vol. 43 (2004) p. 1009, paras. 155 and 159. 
Hadi consistently with Yemen's erga omnes obligations and will not be able to rely on the subsequent agreement where such agreement violates Yemen's obligations.

\section{Treating consent in violation of international obligations as ultra vires}

It is submitted that where a State grants consent such consent, it must generally be consistent with its international law obligations. ${ }^{57}$ The law of treaties as aforementioned, however, seems to favour an approach in which a subsequent agreement, although violating the consenting states international law obligations, concluded with a third state will be valid in as far as the relationship between the parties are concerned. In as far as obligations such as erga omnes obligations are concerned, which cannot be confined to as between the parties, the third state should not, however, be able to rely on the subsequent agreement.

Deeks has argued that '[c]onsent - at least when it is used to affect legal relationships - generally contemplates a transfer only of those rights, privileges, powers, or immunities that the consenting entity itself possesses. ${ }^{58}$ This principle finds broad support in the common law principle that no person can give more rights than he himself possesses. ${ }^{59}$ The relative broad support this principle enjoys worldwide could see it considered a source of international law forming part of the law of civilised nations. ${ }^{60}$

The use of force by an intervening state that violates IHL and/or IHRL would therefore fall beyond the scope of consent granted by the inviting state. This is so particularly in light thereof that important obligations arising from IHL and IHRL are considered to be amongst the most prominent examples of obligations erga omnes. ${ }^{61}$ Wrongfulness for the use of force in such instances would not be precluded even where the consenting State expressly consented to such operation. It is submitted that such responsibility, for the intervening State, arises as a failure by a state in its obligation not to recognise any action inconsistent with an obligation erga omnes is arguably in itself a breach of an international obligation.

\section{The international rule of law}

The international community has furthermore repeatedly emphasised its commitment to the rule of law. ${ }^{62}$ The Secretary General has also emphasised that the rule of law is at the core of the UN's mission and requires, amongst others, measures to 'ensure adherence to the principles of supremacy of law' by both State and private actors. ${ }^{63}$ At the international level, the rule of law does not yet have a strictly defined scope but at a minimum requires that States honour agreements entered into in good faith and fulfil all obligations binding on them under customary international law. ${ }^{64}$ It is submitted that if a State was capable of

\footnotetext{
Byrne, Supra nt. 5, 124.

Deeks, Supra nt. 39, 34.

Ibid.

60 Article 38, United Nations, Statute of the International Court of Justice, 26 June 1945, 33 UNTS 933; The principle forms part of the domestic law of amongst others South Africa, The United States, The United Kingdom, Kenya etc. see in this regard Dukeminier, J. et al, Property (Wolters Kluwer Law \& Business 2017), 707.

61 ILC study on the Diversification and Expansion of International Law, Supra nt. 42, 195.

62 See inter alia UN General Assembly Resolution 67/1.

63 Report of the Secretary General, "The rule of law and transitional justice in conflict and post-conflict societies" S/2004/616 par 6.

64 Chesterman, S., "An International Rule of Law?" 56 American Journal of Comparative Law, (2008), 331361 .
} 
granting what Ashley Deeks refers to as 'unreconciled consent', ${ }^{65}$ the international rule of law would be rendered nugatory.

\section{Is Saudi Arabia Under A Duty to Respect IHL and IHRL Obligations Binding on Yemen?}

From the conclusion that Yemen cannot in general consent to actions which it itself cannot take, it follows that the Saudi Arabian government would to some extent be constrained by the IHL and IHRL obligations binding on Yemen. It is increasingly accepted in international law that certain IHRL treaties such as the International Covenant on Civil and Political Rights (ICCPR) operate extraterritorially. ${ }^{66}$ Saudi Arabia is, however, neither a party to the ICCPR nor to the International Covenant on Economic, Social and Cultural Rights (ICESCR) whereas Yemen is a party to both these IHRL treaties. ${ }^{67}$ The Saudi Arabian intervention in Yemen thus presents a unique case study on the extent to which an intervening state has a duty to respect the IHL and IHRL obligations of the inviting state.

The extent to which the obligations under the ICCPR and the ICESCR are also binding on Saudi Arabia in the ordinary course of international relations, i.e. outside of the intervention by invitation in Yemen, falls beyond the scope of this paper. Suffice it to say, however, that in its operations in Yemen, Saudi Arabia would clearly have to comply with all IHL and IHRL obligations binding on it to the extent that such obligations apply extraterritorially. ${ }^{68}$

\section{A. The res inter alios acta principle}

The Permanent Court of International Justice (P.C.I.J) established that treaties generally only create obligations as between the parties thereto and that in the case of doubt no rights or obligations can be deduced from it in favour of third states. ${ }^{69}$ A treaty to which a State is not a party thus remains res inter alios acta in respect of that State. The fact that the intervening State is, however, constrained thereby that it cannot perform any acts that the host state cannot itself perform indicates that the intervening state is constrained by the negative obligations of the host State to the extent that the agreement providing consent cannot deviate from such negative obligations. ${ }^{70}$ It is, however, submitted that this does not violate the principle that third states are not affected by something that remains res inter alios acta as the intervening state ultimately agrees to accept the invitation to

65 Deeks, Supra nt. 39.

66 The UNHRC has held that States can "be held accountable for violations of rights under the ICCPR which its agents commit on the territory of another State, whether with the acquiescence of the Government of that State or in opposition to it." See inter alia Lopez Burgos $v$ Uruguay, U.N. Doc. CCPR/C/13/D/52/1979, 29 July 1981, para. 12.3; and Celiberti de Casariego v Uruguay, U.N. Doc. CCPR/C/13/D/56/1979, 29 July 1981, para. 10.3.

67 See UN, State Parties to the ICCPR, at <treaties.un.org/Pages/ViewDetails.aspx?src=IND \&mtdsg_no=IV-4\&chapter=4\&clang=_en $>$ (accessed 15 April 2018) and UN, State Parties to the ICESCR, available online at <treaties.un.org/Pages/ViewDetails.aspx?src=IND\&mtdsg_no=IV$3 \&$ chapter $=4 \&$ clang=_en $>$ (last accessed 15 April 2018).

68 See inter alia Pereira Montero v. Uruguay, U.N. Doc. CCPR/C/18/D/106/1981, 31 March 1983, para 5 in which the UNHRC held that "it would be unconscionable to so interpret the responsibility under article 2 of the Covenant as to permit a State party to perpetrate violations of the Covenant on the territory of another State, which violations it could not perpetrate on its own territory."

69 Certain German Interest in Polish Upper Silesia case (1926), ibid., Ser. A, No. 7 par 82.

70 The constraints upon the scope of consent are that of actions which the host state itself cannot perform wherefore positive obligations, such as those arising from certain of the provisions of the ICESCR, would ostensibly remain res inter alios acta. 
intervene and may not act beyond the scope of the host states consent. The intervening state therefore agrees to assume such obligations by accepting the invitation to intervene.

\section{B. IHRL and IHL obligations are generally not Ccpable of being reduced to operate in the bilateral sense}

In the foregoing discussion it had been established that there are instances in which a third State can rely on a subsequent agreement regulating the relations as between itself and another state. This does not, however, apply to obligations erga omnes or those obligations that cannot be meaningfully reduced to operate in the strictly bilateral sense. ${ }^{71}$ The extent to which IHL and IHRL obligation can operate in the bilateral sense would thus impact the extent to which the intervening state must respect the host states IHL and IHRL obligations.

A number of obligations arising from IHL and IHRL do not create reciprocal obligations between States in the bilateralist manner. ${ }^{72}$ This is as the obligations assumed by the State is rather a responsibility a State assumes 'in relation to all persons under its jurisdiction' ${ }^{73}$ It is submitted that where an obligation, such as for example the obligation on the state not to arbitrarily detain persons within its jurisdiction, does not create reciprocal obligations between states in the bilateralist manner, because of the very nature of the obligation, it would not be capable of being excluded in a subsequent agreement. The vast majority of negative IHL and IHRL obligations to which individuals within Yemen are entitled would therefore in turn place legal constraints upon Saudi Arabian operations in Yemen.

The negative obligation not to impair existing access to adequate food arising from the ICESCR, ${ }^{74}$ for example, would thus be binding on Saudi Arabia in its operations in Yemen. In the midst of an armed conflict, such right should, however, be interpreted with reference to the principles of IHL as lex specialis. ${ }^{75}$ If the Saudi Arabia-led blockade, which is widely reported as having impaired access to adequate food ${ }^{76}$ is therefore acting inconsistently with the rules of IHL pertaining to blockades it would also amount to a violation of the right of access to adequate food.

\section{Conclusion}

It can therefore be said that the Saudi Arabia-led intervention has seemingly met all formal requirements for a lawful intervention by invitation. Yemen's invitation to Saudi Arabia and the rest of the GCC should nevertheless be consistent with its international law obligations and the scope of its consent strictly limited to actions that it itself could lawfully have undertaken. It is, however, also true that Yemen can alter its international law obligations as between it and Saudi Arabia where the obligation in question is

71 Jus cogens is not mentioned here but any agreement violating a jus cogens norm would clearly be void.

72 ILC study on the Diversification and Expansion of International Law, Supra nt. 42, p 198.

73 Ibid.

74 UN Committee on Economic, Social and Cultural Rights (CESCR), General Comment No. 12: The Right to Adequate Food (Art. 11 of the Covenant), 12 May 1999 recognises that states have both negative and positive obligations arising from Article 11 of the CESCR.

75 General Comment No. 3 on the African Charter on Human and Peoples' Rights: The Right to Life (Article 4) Adopted during the 57th Ordinary Session of the African Commission on Human and Peoples' Rights held from 4 to 18 November 2015 in Banjul, The Gambia, para 32, at <www.achpr.org /files/instruments/general-comments-right-to-life/general_comment_no_3_english.pdf> (accessed 15 April 2018).

76 Human Rights Watch, "Yemen: Coalition Blockade Imperils Civilians", 7 December 2017, at $<$ hrw.org/news/2017/12/07/yemen-coalition-blockade-imperils-civilians> (accessed 15 April 2018). 
capable of operating in the bilateralist sense. Where it has so altered its international obligations, it would nevertheless remain internationally responsible for the breach of another obligation, binding on it, through this subsequent agreement. In this instance, Saudi Arabia and its GCC partners would, however, be able to rely on this subsequent agreement and would not bear Yemen's responsibility for any breach.

Where the obligation is an obligation erga omnes or by virtue of the nature of the obligation is incapable of being meaningfully reduced to operating reciprocally between two States, the Saudi Arabian government and its coalition partners would not be able to rely on such an agreement. Any consent given by Yemen permitting Saudi Arabia and/or the GCC to violate such obligations are to be rejected as ultra vires. The rejection of such consent given as ultra vires would, in turn, exclude the application of Article 20 DASR and may give rise to the international responsibility of a State acting pursuant to such consent. ${ }^{77}$ In accepting the invitation to intervene in Yemen, Saudi Arabia and its GCC partners also became bound to honour the negative obligations under IHL and IHRL to the extent that such obligations are impacted by the military intervention and the use of force in the territory of Yemen.

www.grojil.org

77 The extent to which individuals, who are the beneficiaries of most IHL and IHRL rights, lack standing before many international tribunals is a relevant question for the enforcement of responsibility but is ultimately a question falling outside the realm of state responsibility. 